Please do not remove this page

RMIT

UNIVERSITY

\title{
The role of social values in the management of ecological systems
}

Ives, Christopher; Kendal, Dave

https://researchrepository.rmit.edu.au/esploro/outputs/9921859577401341/filesAndLinks?institution=61RMIT_INST\&index=null

Ives, C., \& Kendal, D. (2014). The role of social values in the management of ecological systems. Journal of Environmental Management, 144(1), 67-72. https://doi.org/10.1016/j.jenvman.2014.05.013

Document Version: Accepted Manuscript

Published Version: https://doi.org/10.1016/j.jenvman.2014.05.013

Repository homepage: https://researchrepository.rmit.edu.au

(C) 2013 Elsevier. All rights reserved

Downloaded On 2023/04/26 12:28:12 +1000

Please do not remove this page 
Thank you for downloading this document from the RMIT Research Repository.

The RMIT Research Repository is an open access database showcasing the research outputs of RMIT University researchers.

RMIT Research Repository, http://researchbank.rmit.edu.au/

\section{Citation:}

Ives, C and Kendal, D 2014, 'The role of social values in the management of ecological systems', Journal of Environmental Management, vol. 144, no. 1, pp. 67-72.

See this record in the RMIT Research Repository at: https://researchbank.rmit.edu.au/view/rmit:24735

Version: Accepted Manuscript

Copyright Statement: (c) 2013 Elsevier. All rights reserved

Link to Published Version:

http://dx.doi.org/10.1016/j.jenvman.2014.05.013 


\title{
The role of social values in the management of ecological systems
}

\author{
Christopher D. Ives ${ }^{1}$ and Dave Kendal ${ }^{2}$ \\ ${ }^{1}$ School of Global, Urban and Social Studies, RMIT University. GPO Box 2476, Melbourne, \\ 3001 Victoria, Australia. Email christopher.ives@rmit.edu.au \\ 2 Australian Research Centre for Urban Ecology, Royal Botanic Gardens, Melbourne, C/o \\ School of Botany, The University of Melbourne, 3010 Victoria, Australia
}

\begin{abstract}
The concept of value is central to the practice and science of ecological management and conservation. There is a well-developed body of theory and evidence that explores concepts of value in different ways across different disciplines including philosophy, economics, sociology and psychology. Insight from these disciplines provides a robust and sophisticated platform for considering the role of social values in ecological conservation, management and research. This paper reviews theories of value from these disciplines and discusses practical tools and instruments that can be utilised by researchers and practitioners. A distinction is highlighted between underlying values that shape people's perception of the world (e.g. altruistic or biospheric value orientations), and the values that people assign to things in the world (e.g. natural heritage, money). Evidence from numerous studies has shown that there are multiple pathways between these values and attitudes, beliefs and behaviours relevant to ecological management and conservation. In an age of increasing anthropogenic impacts on natural systems, recognising how and why people value different aspects of ecological systems can allow ecological managers to act to minimise conflict between stakeholders and promote the social acceptability of management activities. A series of practical guidelines are provided to enable social values to be better considered in ecosystem management and research.
\end{abstract}

\section{Key words}

Social values, Value orientations, Assigned values, Ecosystems, Conservation, Management.

\section{Introduction}

A dominant objective of ecological management has been to minimise negative human impacts on ecosystems. To achieve this, the dynamics and anthropogenic perturbations of ecological systems have been intensely studied. The resounding call from ecologists and environmental practitioners alike has been for better science and its effective application to practice (McNie, 2007; Sutherland et al., 2004). However, there is increasing recognition that environmental outcomes depend greatly on socio-political factors, in particular the way people think about the environment (Mascia et al., 2003; Robertson and Hull, 2001). The concept of 'values' is therefore becoming increasingly prominent in environmental decisionmaking. As stated by McIntyre (2008, p. 658) "many natural resource conflicts are more about values than they are about facts". 
Environmental managers are trained predominantly in the natural sciences, and social scientists are underrepresented (Endter-Wada et al., 1998). Managers are generally not well versed in methods and literature related to assessing social values and incorporating them into ecological decisions. Even the definition of the term 'value' can be problematic due to its widespread vernacular use and different interpretations and applications by academic disciplines. There can also be anxiety around the application of values to ecological management. Norton and Noonan (2007, p. 665) state that "[e]cologists, worried that they will not be viewed as sufficiently "objective" and "scientific", refuse to consider the important role of values in the development and use of ecological models". Nevertheless, values are a fundamental part of how people engage with conservation issues and provide a "natural connection between place and decision-making” (Brown and Reed, 2012, p. 320). Values must therefore be considered by managers as ignoring them can lead to conflict and poor ecological outcomes (Knight et al., 2011).

It is in this context that we outline the concept of social values. Social values have been explored comprehensively in numerous academic disciplines, including philosophy, economics, sociology and psychology. There have been comprehensive reviews of general environmental values (Dietz et al., 2005; Lockwood, 2005) and social values in forestry (Brown, 1984). However, much of this research is largely inaccessible to environmental practitioners due to the emphasis on theory, the contexts in which it has been applied (e.g. productive forests), and where it is published. In this article we present some of the key understandings of social values in a way that is comprehensible by conservation scientists and environmental managers. We also outline how this understanding might be applied in practical ways to enhance the management of ecosystems.

\section{Theory}

\subsection{Key Concepts}

The many approaches to studying values can be differentiated according to (i) a focus on the values of people compared to how things in the world are valued by people, (ii) different measurement approaches, and (iii) whether values are considered commensurable (see Table 1). The first distinction is particularly relevant in distinguishing between disciplines. In philosophy, sociology and psychology the term 'value' is often used to describe the values of people, namely their preferences for particular means (e.g. integrity) or ends (e.g. social justice) (Brown, 1984). In this sense, values are an important characteristic of people that help shape the judgements they make about the world around them and why different people or social groups make the decisions they do. This class of values has been described as people's underlying values (the term we will use in this paper), held values, or collectively value orientations. A distinction is made between these underlying values and those things in the world that are valued by people. When used in the latter sense, the things being valued are often referred to as a valued objects, and the relative worth given to these objects is referred to as their assigned value (Bengston, 1994; Brown, 1984). Assigned values are the estimated worth of a thing or place (Bengston, 1994). They are the classic subject of economics, which 
typically applies instruments such as market pricing to indicate the worth of goods or services. Ecological managers and conservation practitioners are often more interested in assigned values than underlying values as their activities relate to protecting or managing particular valued objects (i.e. species, ecosystems or places). Indeed, conservation planning tools typically incorporate a system of 'weighting' (or valuing) species according to a set of criteria (e.g. level of threat, ecological function or genetic uniqueness) (Arponen et al., 2005). However, it is increasingly recognised that conservation actions rarely reflect biological priorities in practice (Knight et al., 2008) and that decisions by governing authorities often reflect a different set of social and political 'values' (Brechin et al., 2002). This reality highlights the need to understand the role of assigned and held values in environmental decision-making.

The study of social values can also be differentiated according to method of measurement (quantitative or qualitative) (Table 1). Examples of quantitative measurement of values include market pricing in economics, and the use of psychometric scales in psychology (Bengston, 1994). This allows (i) values to be measured for large and diverse groups of people, (ii) changes in values to be tracked across groups of people or across time, and (iii) models to be developed to predict values based on other factors (e.g. demographics, cultural background). In contrast, sociology and anthropology often use qualitative techniques that allow the values of a particular culture or population to be understood in much greater depth but make generalisation difficult.

The commensurability of values is their ability to be reduced to a single scale of measurement that allows them to be compared directly (Bengston, 1994). Commensurability of values is a fundamental principal underpinning cardinal utility theory, where many objects can be valued using a common standard: typically money (Farber et al., 2002). Where market pricing is not possible, methods such as contingent valuation (e.g. willingness to pay) are used to measure and convert a wide range of assigned values into money to allow direct comparison and make value trade-offs. However, Chan et al. (2012) note that cultural services and non-use values of ecosystems are difficult to quantify because they are intangible and incommensurable. They are irreducible to a single common scale and do not conform to the neoclassical economic assumptions. In contrast to economics, values in psychology are measured on independent scales that allow intra-value comparison across people or time, but not inter-value comparisons to be made. This approach is consistent with the philosophy of value pluralism, treating values as incommensurable and unable to be converted to a single unit of measure (Bengston, 1994; Lockwood, 1999). 
Table 1. Commonly used approaches to studying values.

\begin{tabular}{|c|c|c|c|c|c|c|c|}
\hline Description & Disciplines & $\begin{array}{l}\frac{\mathscr{g}}{3} \\
\frac{\pi}{2} \\
\frac{0}{9} \\
\frac{0}{1}\end{array}$ & 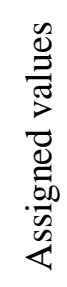 & 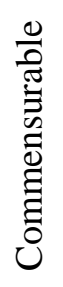 & 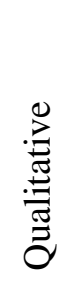 & 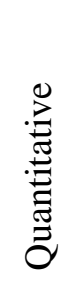 & Examples \\
\hline $\begin{array}{l}\text { Explores the meanings and } \\
\text { ethical implications of } \\
\text { values }\end{array}$ & Philosophy & $\checkmark$ & & & $\checkmark$ & & $\begin{array}{l}\text { Plumwood } \\
\text { (2002), } \\
\text { Rolston (1994) }\end{array}$ \\
\hline $\begin{array}{l}\text { Measures a comprehensive } \\
\text { set of underlying and } \\
\text { assigned values for specific } \\
\text { or abstract places/concepts }\end{array}$ & Psychology & $\checkmark$ & $\checkmark$ & & & $\checkmark$ & $\begin{array}{l}\text { Stern \& Dietz } \\
\text { (1994), Ford } \\
\text { (2009) }\end{array}$ \\
\hline $\begin{array}{l}\text { Identifies the value } \\
\text { relationships between } \\
\text { particular people(s) and } \\
\text { particular place(s) }\end{array}$ & $\begin{array}{l}\text { Human } \\
\text { Geography, } \\
\text { Sociology, } \\
\text { Anthropology }\end{array}$ & $\checkmark$ & $\checkmark$ & & $\checkmark$ & & $\begin{array}{l}\text { Graham et al. } \\
\text { (2013), } \\
\text { Stephenson } \\
\text { (2008) }\end{array}$ \\
\hline $\begin{array}{l}\text { Measures assigned values, } \\
\text { typically using a common } \\
\text { value scale (e.g. money, } \\
\text { conservation value) }\end{array}$ & $\begin{array}{l}\text { Economics, } \\
\text { Conservation } \\
\text { science }\end{array}$ & & $\checkmark$ & $\checkmark$ & & $\checkmark$ & $\begin{array}{l}\text { Costanza et al., } \\
\text { (1997), Bottrill } \\
\text { (2008) }\end{array}$ \\
\hline
\end{tabular}

Values must be distinguished from related concepts such as attitudes, beliefs and norms (Dietz et al., 2005). Attitudes are statements of people's positive or negative evaluations of a specific object or situation, and are typically expressed as likes or dislikes, or preferences. Beliefs are statements of people's understanding of the world; "they are facts as an individual perceives them” (Dietz et al., 2005, p. 346). Norms are common understandings about how people ought to behave in a certain context (Dietz et al., 2005) and can operate at the individual or group level. A useful heuristic to understand the relationships between these psychological elements is the cognitive hierarchy model of human behaviour (Rokeach, 1973). It proposes that behaviours are influenced by attitudes, beliefs and values. The higher order cognitive factors (such as behavioural intentions) are more numerous and changeable, and are preceded by fewer and more stable concepts (such as values). This is depicted by the Figure 1 schematic adapted from Fulton et al. (1996). 


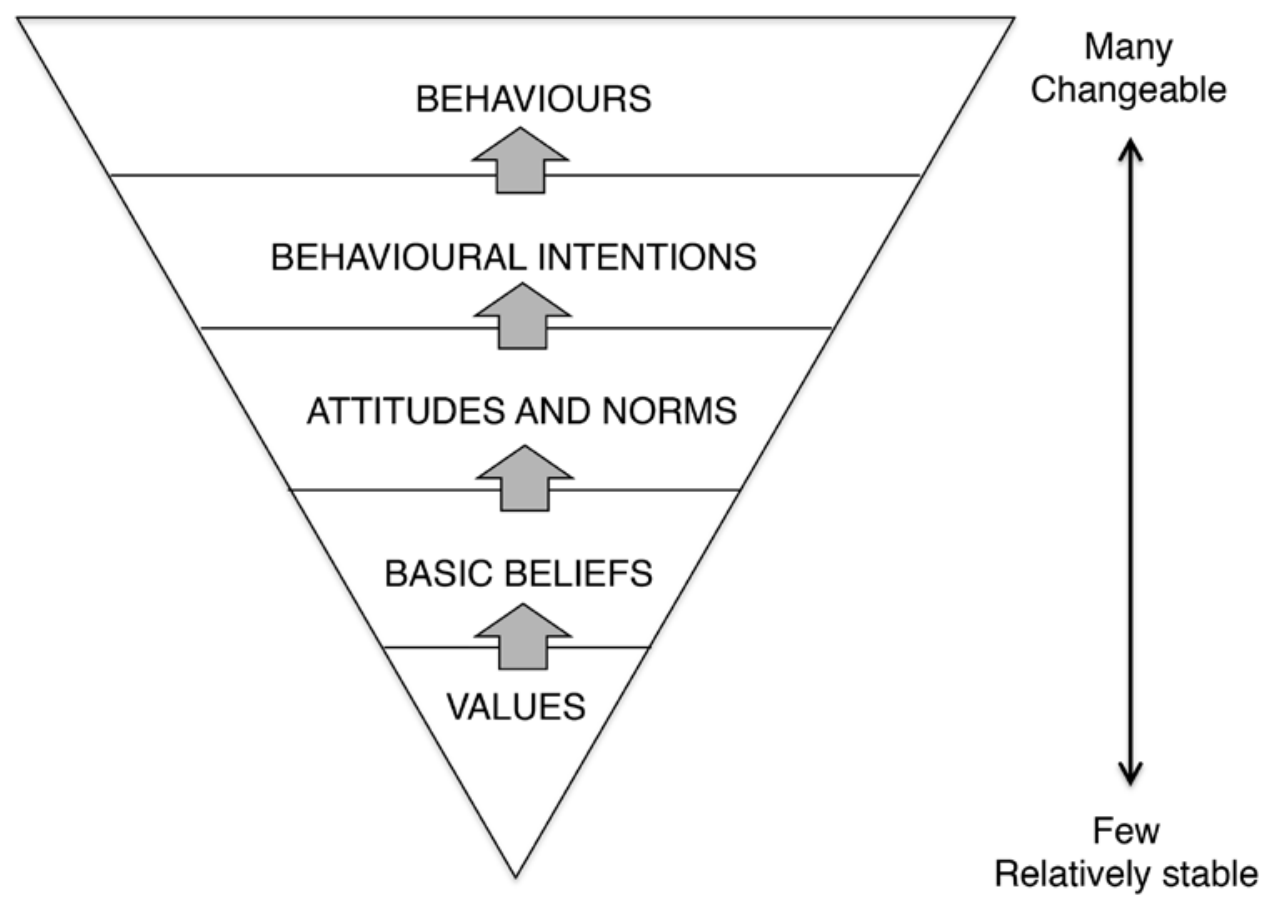

Figure 1: A visual representation of the cognitive hierarchy. Concepts towards the bottom are more stable and fewer in number than those towards the top.

\subsection{The nature and structure of environmental values: Theoretical basis.}

Environmental psychology is an interdisciplinary field that explores the interplay between people and their environment. It uses psychological methods to collect and analyse data but draws upon theory and knowledge from many disciplines such as social psychology, sociology and the environmental sciences (Steg et al., 2013). Research in environmental psychology has explored how underlying values relate to environmental issues and specific instruments have been developed to measure environmental values.

Research on underlying values in psychology has identified a range of values that guide people's judgements of the world around them (Rokeach, 1973; Schwartz, 1992). Underlying values specifically related to the environment have been identified based on this framework. Environmental value orientations labelled as Biospheric (nature centred), Social Altruistic (human centred) and Egoistic (self-centred) have been identified and shown to predict proenvironmental behaviours and attitudes (Schultz, 2001; Stern et al., 1995). Related frameworks have been developed, which distinguish between ecocentric and anthropocentric environmental values (e.g. Thompson and Barton, 1994). Other research grounded in an economic framework has concluded that environmental values can be structured according to three categories: intrinsic, use and non-use (Lockwood, 1999; Winter and Lockwood, 2003). Research has shown that these values are good predictors of people's judgement of management decisions, such as clear-felling in native forests (Ford et al., 2009). The various frameworks for understanding underlying environmental values hold many themes in common, and collectively suggest that there are multiple ways that people value nature. 
There has been comparatively little environmental psychological research into assigned values for the environment, as studies of assigned values tend to be very place specific with limited possibility of generalising findings. However numerous studies in geography, anthropology and sociology have used both qualitative and quantitative techniques to explore the values people assign to particular places (e.g. McIntyre et al., 2008; Raymond and Brown, 2006). Public Participatory GIS is becoming widely used to explore how people's values are assigned to places in the landscape (Brown, 2012), and other forms of value mapping are being incorporated into planning and management processes (McIntyre et al. 2008). Knowing the values that people assign to a landscape is useful in environmental management since assigned values apply more directly to management goals and actions (Seymour et al., 2010). However, recent research has shown that underlying values underpin and relate to assigned values (Ives and Kendal 2013; Kaltenborn and Bjerke, 2002).

\subsection{Relationship between values and behaviour}

How these values relate to behaviour is also important to environmental managers, since behaviour ultimately affects environmental outcomes (Schultz, 2011). The Theory of Planned Behaviour (Ajzen, 1991) is one of the dominant theories of behaviour in psychology. The theory argues that cognitive structures (e.g. attitudes, beliefs, norms and values) are good predictors of behavioural intentions, but that there are many barriers between behavioural intentions and actual behaviours.

Pro-environmental behaviour has been explicitly linked to environmental values in a number of studies by Paul Stern and others (Stern and Dietz, 1994; Stern et al., 1995, 1993). This work has since been expanded to explore the relationship between environmental value orientations and behavioural intentions (de Groot and Steg, 2007) and the role of values, beliefs and norms in pro-environmental behaviour (Steg and Vlek, 2009; Stern, 2000). Drawing heavily upon the Theory of Planned Behaviour, Values-Belief-Norm (VBN) theory asserts that people's underlying values influence general beliefs about the environment (e.g. humanity's need to live in harmony with the rest of the environment), and specific beliefs about the consequences of environmental change on the things they value (e.g. family security). These beliefs in turn affect people's perceptions of their ability to reduce the threat to the things they value, which influence actions that are typically taken (personal norms). Importantly, VBN theory stresses that pro-environmental behaviour can be underpinned by different value orientations. In this way, the same action might be taken by people with an Egoistic value orientation (believing it would benefit themselves) and those with a Biospheric orientation (believing it would benefit the environment).

The VBN theory has been tested and validated in a range of contexts, such as vegetation planting by private landholders (Raymond et al., 2011), the acceptability of policies to reduce household $\mathrm{CO}_{2}$ emissions (Steg et al., 2005), and the willingness of city residents to pay for a suburban park (López-Mosquera and Sánchez, 2012). However, there is a need for more research on the role of assigned values in driving behaviour (Seymour et al., 2010), particularly in the context of ecological management. 


\section{Tools for applying values research to ecological management.}

A number of practical tools exist that may be used by ecological managers to measure people's values. Expertise in the social sciences is necessary to comprehensively understand the underlying or assigned values relevant to a particular context, to design a survey that measures intended values, and to interpret findings. Such work should therefore be conducted in partnership with people with appropriate skills.

\subsection{Psychometric Scales}

The scale used by Stern et al. (1995) to measure environmental value orientations (Biospheric, Altruistic and Egoistic) has been validated in a number of contexts. Applying the scale can be useful for understanding the composition of different value orientations towards the environment in a target population (e.g. the visiting public to a reserve or environmental volunteers). Other scales have been developed that are more relevant in specific management contexts. For example, Fulton et al. (1996) proposed a model of eight basic wildlife value orientations according to people's values and beliefs. These were found to organise into the following four dimensions according to survey responses: (1) hunting/anti-hunting, (2) residential wildlife experience, (3) wildlife education, and (4) fishing/anti-fishing. Understanding the composition of wildlife values within a community can significantly improve the effectiveness of policies to manage wildlife interactions through predicting likely threats and tailoring messages to be more accurately received by the public.

Winter and Lockwood (2003) developed a 'natural area value scale' to assess the degree to which individuals assigned intrinsic, non-use and use values to natural areas. They found that use values have recreation and non-recreation components, and that the scale categories were related to management preferences. This tool is a good example of how less tangible assigned values can be elicited and applied to management contexts. This scale has subsequently been refined to measure religious-spiritual values (Winter, 2007) and aesthetic values (Ford et al., 2012).

A number of other related instruments have been developed, and are widely used, that are based on beliefs and/or attitudes rather than values. The New Environmental Paradigm (Dunlap and Van Leire, 1978) is one of the most common. While there are important theoretical differences between beliefs and values, in practice they measure closely related concepts and may be used in similar ways.

\subsection{Spatial Mapping of Values}

Measuring and applying social values related to specific spatial areas can be especially useful in ecological management. One of the most common tools to measure values spatially is Public Participation GIS (PPGIS), which involves stakeholders interacting with map products (physical or electronic/online) to generate new information about a landscape (Brown, 2012). Landscape values are some of the most commonly mapped attributes using these methods. For example, Raymond and Brown (2006) measured the strength and distribution of 12 assigned values for the Otways region in Victoria, and compared private and public lands. 
This information underpinned recommendations on where future protected areas should be located.

Values mapping has also been utilised in urban settings. Tyrväinen et al. (2003) explored the compatibility of aesthetic and ecological values in urban forests. Tyrväinen (2007) built upon this work by mapping the values assigned by Helsinki residents to green spaces via a postal questionnaire. 'The use of this technique enabled identification of green spaces in the city that were valued most highly for different reasons (e.g. 'peace and quiet' or 'valuable nature site').

Spatially mapped values can also be integrated with biophysical data and applied to conservation planning and management. For example, Whitehead et al. (2014) used spatial conservation planning software to combine social values for biodiversity (gathered from a community PPGIS survey) with modelled species distributions to generate various conservation planning scenarios. This information is useful for minimising conflict around different land use categories or maximising the acceptability of ecological management actions.

\section{Guidelines for Ecological Managers}

\subsection{Why values matter}

Applying knowledge of social values has potential to vastly improve the management of ecosystems. In particular, there are five areas of consistent findings in the environmental values literature which apply to the management of ecological systems, namely (i) values change over time, (ii) values differ between groups of people, (iii) multiple values can be assigned to the same places, (iv) multiple pathways exist between values, attitudes and behaviours towards ecosystems and (v) values influence people's judgement of management decisions.

In forestry, longitudinal research has shown that society's values for productive forest uses have declined, while other values (e.g. biocentric, spiritual) have increased (Bengston et al., 2004; Xu and Bengston, 1997). While forest managers were historically focussed on effective and sustainable timber production, modern forestry must now manage for a range of values that can require tradeoffs (Rolston and Coufal, 1991). This scenario is by no means exclusive to forestry. The importance of protected areas for various functions has also changed. While national parks were originally established for the public's enjoyment, with recreational and aesthetic considerations of greatest significance (Sellars, 1997), protected areas are today recognised as critical to achieving biodiversity conservation outcomes (Brooks, 2010). However, in some contexts, such as Australia's national parks, political and economic conditions are tending to raise the profile of more utilitarian functions of protected areas to the detriment of biodiversity (Ritchie et al., 2013).

Research on underlying and assigned environmental values has revealed that different underlying value orientations will be expressed in various assigned values related to a particular ecosystem or environmental issue. Commonly, a heterogeneity of values (held and 
assigned) is present among diverse groups of stakeholders (for example ecological managers, resource users, environmentalists) and the general public (Ford et al., 2009; Seymour et al., 2011). Studies also show that individuals can hold apparently conflicting values (e.g. valuing both production and conservation). For example, in their study of attitudes towards the control of mosquitos in Sweden, Ojala and Lidskog (2011) found that despite an apparent public consensus towards intervention, individuals often held strong values for biodiversity protection alongside conflicting (and dominating) quality of life concerns. This and other research emphasises that a multiplicity of environmental values can lead to outward or internal conflict when the values important to people are not being considered adequately by land managers (Bengston, 1994).

Values research shows that there can be different value-based pathways that different people use when considering a particular place. For example, people with a Biospheric value orientation may value an urban park for the biodiversity present, while people with a Social Altruistic value orientation may value the same park for its opportunities for socialising such as the presence of picnic tables. Finally, people with an Egositic value orientation may value the same park for the particular recreational facilities that they use. Understanding the values of the people using a particular place can help to inform management decisions.

Of particular practical use is research that relates values to judgement of management decisions. Research in forestry has shown that acceptability of clearfell harvesting is related strongly to people's values for natural areas (Ford et al., 2009). The study revealed that people with stronger use values (e.g. producing timber) were more likely to find clearfelling acceptable than those with stronger intrinsic values for nature. In their study of Melbourne's peri-urban agricultural landscape, Ives and Kendal (2013) found significant relationships between Biospheric underlying values and 'multifunctional' assigned values (including items about culture, education, aesthetics and environment), and between multifunctional assigned values and preferences for all landscape types. Furthermore, other studies have shown relationships between values and trust in management (e.g. Ford et al., 2012; Vaske et al., 2007).

\subsection{Necessary management considerations}

Ecological managers who understand the values of relevant stakeholders position themselves to maximise the social acceptability of management actions and minimise potential conflict. Indeed, "values information can be used effectively to identify landscapes that have special meanings" and "to identify potential conflicts among special interest groups early in the planning and management decision-making process” (Zube, 1987, p. 44). This ultimately will help to improve ecological and social outcomes, particularly in areas that experience significant human interaction.

Values information can be usefully applied by managers in a number of ways. First, the multiplicity of values held by stakeholders suggests that pitching messages in different ways can appeal more effectively to a diverse audience. Many conservation messages fail to be as effective as they could be because the message is framed in a way that only a subset of people 
will consider important. For example, a sign imploring walkers not to deviate from a path because of the resulting impacts on sensitive plants may influence someone who values the park for its biodiversity conservation more than a person who values the park for its visual beauty. If ecological outcomes are dependent on human behaviour, then ecological managers must consider carefully how to design communication strategies for greatest effect.

Second, knowing the values of relevant stakeholders can help predict what actions or messages are likely to generate negative responses. This information can help ecological managers avoid conflict. If burning vegetation or culling animals is necessary to maintain the health of an ecosystem, it is likely that people with strong values for human safety or animal wellbeing will react passionately against such actions. Understanding people's values in advance can help ecological managers communicate clearly to the public before taking action, and align messages appropriately. For example, instead of emphasising the ecological benefits, care might be taken instead to stress the safety measures that have been put in place when burning.

Finally, positive overlaps in values related to different land use types should be sought out. This has been conducted spatially in a number of settings. For example, Brown and Reed (2012) conducted a "value compatibility analysis" in Oregon, U.S.A. to determine where All Terrain Vehicle (ATV) use may occur within a National Forest without compromising the other values assigned by the public to the park. Compatibility scores between ATV use and 12 other values were determined by surveying residents and were mapped accordingly. This information enabled the managers to determine trade-off and compatibility areas.

\subsection{Questions ecological managers need to ask}

Given the effect that social values can have on ecological management outcomes, ecological practitioners should ask a series of questions to guide how values research is best applied to a particular context. Different information gathering techniques will suit different questions and range from applying psychometric scales developed from previous research to qualitative interview exploration (see Kempton et al., 1995 for a useful exploration of typical anthropological techniques). We note that it is unreasonable to expect ecological practitioners to possess expertise in social and ecological sciences to a depth and breadth necessary to tackle such complex environmental management challenges (Heberlein, 2012; Lowe et al., 2009). Nevertheless, a basic understanding of these techniques is a valuable asset and can aid in interdisciplinary collaboration between experts in different fields (Mascia et al., 2003; Sandbrook et al., 2013).

The first question is 'whose values are relevant?'. Even decisions that are made on the basis of sound science can face challenges in implementation if the values of key stakeholders have not been considered. Stakeholder groups include park visitors, the general public, or even those in charge of decision-making. Stakeholder analysis techniques (Reed et al., 2009) may be useful in ascertaining which groups of people need to be understood in most detail. It is important to note that not all management decisions need to account for values; many are 
purely technical. However, we assert that thinking about whose values might be relevant is a worthwhile exercise regardless.

The second question to be considered by managers is 'what kinds of social values are relevant and how can they be measured?'. An understanding of underlying values might be most useful if seeking to explain why people think or act the way they do, while the assigned values within a management unit may be more useful to know when determining how to manage particular assets.

The final question that should be asked is 'which values do management goals reflect?'. Any goal that is set by a management organisation finds its roots in a value of some kind (Keeney, 1996). Knowing the underlying values behind management goals can have significant implications for how actions are implemented and messages communicated. For example, a goal of maintaining the persistence of a faunal species is likely to be driven by an ecocentric set of values, while ensuring safe walking tracks is likely to be underpinned by values grounded in human well-being. While these goals are likely to reflect broader values in society rather than those of individuals (and may be determined by external legal triggers), at other times they are shaped by managers. It is important that ecological managers are conscious of their own values and how these influence the goals they set, ideals they aspire towards and actions they take. Being cognisant of the underlying value basis of management goals is particularly important when incompatibilities arise (such as managing for human use of biodiversity as well as conservation goals).

\section{Conclusion}

It is clear from the research discussed in this article that values are a critical part of ecological management in a world where more and more species are increasingly sharing space with humans. No longer can ecological management progress on biophysical knowledge alone; every action and intervention is drenched in human values of some kind. The long history of research into human values from a variety of disciplinary perspectives has made it difficult for ecologists to penetrate this literature and apply it. However, this research has provided rich resources that can be mined and applied to new contexts. This article has sought to provide a portal into relevant knowledge of human values and translate it to the ecological management context. Although much research is still needed (especially on how values relate to more specific ecological topics such as biodiversity and ecosystem function), we encourage ecological managers to be conscious of and engage with values in the era of "post-normal science” (Funtowicz and Ravetz, 1993). Integration of values with ecological practice and research will help improve the protection and management of ecological systems and reveal greater insights into how people relate to their environment.

\section{Acknowledgements}

The authors would like to thank the participants of a number of value-based studies that have contributed to the ideas presented in this article. CDI receives funding support from the 
Australian Research Council Centre of Excellence for Environmental Decisions, and the Australian Government's National Environmental Research Program.

\section{References}

Ajzen, I., 1991. The theory of planned behavior. Organ. Behav. Hum. Decis. Process. 50, 179-211.

Arponen, A., Heikkinen, R.K., Thomas, C.D., Moilanen, A., 2005. The Value of Biodiversity in Reserve Selection: Representation, Species Weighting, and Benefit Functions. Conserv. Biol. 19, 2009-2014.

Bengston, D., Webb, T., Fan, D., 2004. Shifting Forest Value Orientations in the United States, 1980-2001: A Computer Content Analysis. Environ. Values 13, 373-392.

Bengston, D.N., 1994. Changing forest values and ecosystem management. Soc. Nat. Resour. An Int. J. 7, 515-533.

Bottrill, M.C., Joseph, L.N., Carwardine, J., Bode, M., Cook, C., Game, E.T., Grantham, H., Kark, S., Linke, S., McDonald-Madden, E., Pressey, R.L., Walker, S., Wilson, K.A., Possingham, H.P., 2008. Is conservation triage just smart decision making? Trends Ecol. Evol. 23, 649-654.

Brechin, S., Wilshusen, P., Fortwangler, C., West, P., 2002. Beyond the square wheel: toward a more comprehensive understanding of biodiversity conservation as social and political process. Soc. Nat. Resour. 15, 41-64.

Brooks, T., 2010. Conservation planning and priorities, in: Sodhi, N.S. and Ehrlich, P.R. (Eds.), Conservation Biology for All. Oxford University Press, Oxford, pp. 199-219.

Brown, G., 2012. Public Participation GIS (PPGIS) for regional and Environmental Planning: reflections on a decade of Empirical research. URISA J. 25, 7-18.

Brown, G., Reed, P., 2012. Values Compatibility Analysis: Using Public Participation Geographic Information Systems (PPGIS) for Decision Support in National Forest Management. Appl. Spat. Anal. Policy 5, 317-332.

Brown, T., 1984. The Concept of Value in Resource Allocation. Land Econ. 60, 231-246.

Chan, K.M.A., Satterfield, T., Goldstein, J., 2012. Rethinking ecosystem services to better address and navigate cultural values. Ecol. Econ. 74, 8-18.

Costanza, R., D’Arge, R., De Groot, R., Farber, S., Grasso, M., Hannon, B., Limburg, K., Naeem, S., O’Neill, R.V., Paruelo, J., others, 1997. The value of the world's ecosystem services and natural capital. Nature 387, 253-260.

De Groot, J.I.M., Steg, L., 2007. Value Orientations to Explain Beliefs Related to Environmental Significant Behavior: How to Measure Egoistic, Altruistic, and Biospheric Value Orientations. Environ. Behav. 40, 330-354.

Dietz, T., Fitzgerald, A., Shwom, R., 2005. Environmental Values. Annu. Rev. Environ. Resour. 30, 335-372.

Dunlap, R., Van Leire, K., 1978. The New Environmental Paradigm. J. Environ. Educ. 9, 1019.

Endter-Wada, J., Blahna, D., Krannich, R., Brunson, M., 1998. A Framework for Understanding Social Science Contributions to Ecosystem Management. Ecol. Appl. 8, 891-904. 
Farber, S.C., Costanza, R., Wilson, M.A., 2002. Economic and ecological concepts for valuing ecosystem services. Ecol. Econ. 41, 375-392.

Ford, R.M., Williams, K.J.H., Bishop, I.D., Webb, T., 2009. A value basis for the social acceptability of clearfelling in Tasmania, Australia. Landsc. Urban Plan. 90, 196-206.

Ford, R.M., Williams, K.J.H., Smith, E.L., Bishop, I.D., 2012. Beauty, Belief, and Trust: Toward a Model of Psychological Processes in Public Acceptance of Forest Management. Environ. Behav.

Fulton, D.C., Manfredo, M.J., Lipscomb, J., 1996. Wildlife value orientations: A conceptual and measurement approach. Hum. Dimens. Wildl. 1, 24-47.

Funtowicz, S., Ravetz, J., 1993. Science for the post-normal age. Futures 739-755.

Graham, S., Barnett, J., Fincher, R., Hurlimann, A., Mortreux, C., Waters, E., 2013. The social values at risk from sea-level rise. Environ. Impact Assess. Rev. 41, 45-52.

Heberlein, T.A., 2012. Navigating Environmental Attitudes. Conserv. Biol. 26, 583-585.

Ives, C.D., Kendal, D., 2013. Values and attitudes of the urban public towards peri-urban agricultural land. Land Use Policy 34, 80-90.

Kaltenborn, B.P., Bjerke, T., 2002. Associations between environmental value orientations and landscape preferences. Landsc. Urban Plan. 59, 1-11.

Keeney, R., 1996. Value-focused thinking: Identifying decision opportunities and creating alternatives. Eur. J. Oper. Res. 2217, 4-5.

Kempton, W., Boster, J., Hartley, J., 1995. Environmental Values in American Culture. MIT Press, Cambridge, MA.

Knight, A., Cowling, R., Rouget, M., Balmford, A., Lombard, A.T., Campbell, B.M., 2008. Knowing But Not Doing: Selecting Priority Conservation Areas and the Research Implementation Gap. Conserv. Biol. 22, 610-617.

Knight, A.T., Sarkar, S., Smith, R.J., Strange, N., Wilson, K.A., 2011. Engage the hodgepodge: management factors are essential when prioritizing areas for restoration and conservation action. Divers. Distrib. 17, 1234-1238.

Lockwood, M., 1999. Humans valuing nature: Synthesising insights from philosophy, psychology and economics. Environ. Values 8, 381-401.

Lockwood, M., 2005. Integration of natural area values: conceptual foundations and methodological approaches. Australas. J. Environ. Manag. 12, 8-19.

López-Mosquera, N., Sánchez, M., 2012. Theory of Planned Behavior and the Value-BeliefNorm Theory explaining willingness to pay for a suburban park. J. Environ. Manage. 113, 251-262.

Lowe, P., Whitman, G., Phillipson, J., 2009. Ecology and the social sciences. J. Appl. Ecol. 46, 297-305.

Mascia, M.B., Brosius, J.P., Dobson, T.A., Forbes, B.C., Horowitz, L., McKean, M.A., Turner, N.J., 2003. Conservation and the Social Sciences. Conserv. Biol. 17, 649-650.

McIntyre, N., Moore, J., Yuan, M., 2008. A Place-Based, Values-Centered Approach to Managing Recreation on Canadian Crown Lands. Soc. Nat. Resour. 37-41.

McNie, E., 2007. Reconciling the supply of scientific information with user demands: an analysis of the problem and review of the literature. Environ. Sci. Policy 10, 17-38.

Norton, B.G., Noonan, D., 2007. Ecology and valuation: Big changes needed. Ecol. Econ. 63, 664-675. 
Ojala, M., Lidskog, R., 2011. What Lies Beneath the Surface? A Case Study of Citizens' Moral Reasoning with Regard to Biodiversity. Environ. Values 20, 217-237.

Plumwood, V., 2002. Environmental Culture: the Ecological Crisis of Reason. Routledge.

Raymond, C., Brown, G., 2006. A Method for assessing protected area allocations using a typology of landscape values. J. Environ. Plan. Manag. 49, 797-812.

Raymond, C.M., Brown, G., Robinson, G.M., 2011. The influence of place attachment, and moral and normative concerns on the conservation of native vegetation: A test of two behavioural models. J. Environ. Psychol. 31, 323-335.

Reed, M.S., Graves, A., Dandy, N., Posthumus, H., Hubacek, K., Morris, J., Prell, C., Quinn, C.H., Stringer, L.C., 2009. Who's in and why? A typology of stakeholder analysis methods for natural resource management. J. Environ. Manage. 90, 1933-49.

Ritchie, E.G., Bradshaw, C.J. a, Dickman, C.R., Hobbs, R., Johnson, C.N., Johnston, E.L., Laurance, W.F., Lindenmayer, D., McCarthy, M. A, Nimmo, D.G., Possingham, H.H., Pressey, R.L., Watson, D.M., Woinarski, J., 2013. Continental-Scale Governance and the Hastening of Loss of Australia’s Biodiversity. Conserv. Biol. 27, 1133-5.

Robertson, D.P., Hull, R.B., 2001. Beyond Biology: toward a More Public Ecology for Conservation. Conserv. Biol. 15, 970-979.

Rokeach, M., 1973. The nature of human values. Free Press, New York.

Rolston, H., 1994. Value in Nature and the Nature of Value. R. Inst. Philos. Suppl. 36, 13-30.

Rolston, H., Coufal, J., 1991. A forest ethic and multivalue forest management. J. For. 89, 35-40.

Sandbrook, C., Adams, W.M., Büscher, B., Vira, B., 2013. Social Research and Biodiversity Conservation. Conserv. Biol. 00, 1-4.

Schultz, P.W., 2001. The Structure of Environmental Concern: Concern for Self, Other People, and the Biosphere. J. Environ. Psychol. 21, 327-339.

Schultz, P.W., 2011. Conservation means behavior. Conserv. Biol. 25, 1080-3.

Schwartz, S.H., 1992. Universals in the content and structure of values: Theoretical advances and empirical tests in 20 countries, in: Zanna, M. (Ed.), Advances in Experimental Social Psychology. Academic, Orlando, Florida, pp. 1-65.

Sellars, R., 1997. Preserving Nature in the National Parks: A history. Yale University Press, New Haven.

Seymour, E., Curtis, A., Pannell, D., 2010. Understanding the role of assigned values in natural resource management. Australas. J. Environ. Manag. 17, 142-153.

Seymour, E., Curtis, A., Pannell, D.J., Roberts, A., Allan, C., 2011. Same river, different values and why it matters. Ecol. Manag. Restor. 12, 207-213.

Steg, L., Dreijerink, L., Abrahamse, W., 2005. Factors influencing the acceptability of energy policies: A test of VBN theory. J. Environ. Psychol. 25, 415-425.

Steg, L., van den Berg, A., de Groot, J.I.M., 2013. Environmental Psychology: An introduction. BPS Blackwell, Chichester.

Steg, L., Vlek, C., 2009. Encouraging pro-environmental behaviour: An integrative review and research agenda. J. Environ. Psychol. 29, 309-317.

Stephenson, J., 2008. The Cultural Values Model: An integrated approach to values in landscapes. Landsc. Urban Plan. 84, 127-139. 
Stern, P.C., 2000. Toward a Coherent Theory of Environmentally Significant Behavior. J. Soc. Issues 56, 407-424.

Stern, P.C., Dietz, T., 1994. The Value Basis of Environmental Concern. J. Soc. Issues 50, 65-84.

Stern, P.C., Dietz, T., Kalof, L., 1993. Value Orientations, Gender, and Environmental Concern. Environ. Behav. 25, 322-348.

Stern, P.C., Kalof, L., Dietz, T., Guagnano, G.A., 1995. Values, Beliefs, and Proenvironmental Action: Attitude Formation Toward Emergent Attitude Objects. J. Appl. Soc. Psychol. 25, 1611-1636.

Sutherland, W.J., Pullin, A.S., Dolman, P.M., Knight, T.M., 2004. The need for evidencebased conservation. Trends Ecol. Evol. 19, 305-8.

Thompson, S.C.G., Barton, M.A., 1994. Ecocentric and anthropocentric attitudes towards the environment. J. Environ. Psychol. 149-157.

Tyrväinen, L., Mäkinen, K., Schipperijn, J., 2007. Tools for mapping social values of urban woodlands and other green areas. Landsc. Urban Plan. 79, 5-19.

Tyrväinen, L., Silvennoinen, H., Kolehmainen, O., 2003. Ecological and aesthetic values in urban forest management. Urban For. Urban Green. 1, 135-149.

Vaske, J.J., Absher, J.D., Bright, A.D., 2007. Salient value similarity, social trust and attitudes toward wildland fire management strategies. Hum. Ecol. Rev. 14, 223-232.

Whitehead, A.L., Kujala, H., Ives, C.D., Gordon, A., Lentini, P.E., Wintle, B.A., Nicholson, E., Raymond, C.M., 2014. Integrating biological and social values when prioritizing places for biodiversity conservation. Conserv. Biol.

Winter, C., 2007. The Intrinsic, Instrumental and Spiritual Values of Natural Area Visitors and the General Public: A Comparative Study. J. Sustain. Tour. 15, 599-614.

Winter, C., Lockwood, M., 2003. The natural area value scale. Australas. J. Environ. Manag. 2003.

Xu, Z., Bengston, D.N., 1997. Trends in national forest values among forestry professionals, environmentalists, and the news media, 1982-1993. Soc. Nat. Resour. 10, 43-59.

Zube, E.H., 1987. Perceived land use patterns and landscape values. Landsc. Ecol. 1, 37-45. 